\title{
I.O. Моісеснко
}

\section{АСОЦІАЦЯ С825Т ПОЛІМОРФІЗМУ ГЕНА ВЗ-СУБОДИНИЦІ G-ПРОТЕЇНУ 3 АРТЕРІАЛЬНОЮ ГІПЕРТЕНЗІЕЮ}

Сумський державний університет

\begin{abstract}
Резюме. Метою дослідження було вивчення асоціації C825T поліморфізму гена $\beta 3$-субодиниці Gпротеїну з артеріальною гіпертензією (АГ) та прогнозування ризику розвитку АГ. Обстежено 155 хворих на АГ та 50 практично здорових осіб. Виявлено, що у хворих на АГ більш розповсюдженим $є$ алель Т. Серед
\end{abstract}

Вступ. Артеріальна гіпертензія (АГ) є провідною медико-соціальною проблемою. За прогнозами ВОО3 до 2020 року серцево-судинні захворювання (СС3) переважатимуть інфекційні хвороби як провідну причину смерті та інвалідності, при цьому ішемічна хвороба серця (IXC) посідатиме перше, а цереброваскулярні хвороби (ЦВХ) - четверте місце в усьому світі. Ці причини дуже тісно пов'язані з АГ. За результатами досліджень Міжнародного товариства з вивчення АГ, близько $54 \%$ всіх інсультів, $47 \%$ випадків IXC і $25 \%$ інших ССЗ зумовлені наявністю АГ. Виникнення АГ залежить від професійної діяльності населення, характеру харчування, частоти чинників ризику (надмірна маса тіла, дисліпопротеїнемія), рівня психоемоційного напруження, а також - від поширеності шкідливих звичок (куріння, вживання алкогольних напоїв тощо) [2].

Останніми роками ведеться активний пошук "генів-кандидатів", відповідальних за розвиток АГ. Накопичено дані про участь у патогенезі АГ генів ангіотензинперетворюючого ферменту, рецептора ангіотензину -2 типу 1 , хімази серця, ендотеліальної NO--синтази та синтази альдостерону [1]. Окрім генів, що кодують компоненти ренін-ангіотензин-альдостеронової системи, важливу роль у розвитку АГ і ремоделюванні серцево-судинної системи (ССС) можуть відігравати гени, що кодують синтез білків-трансдукторів, що здійснюють передачу сигналів від гормонів і вазоактивних речовин. У зв'язку з цим, велику увагу приділяють дослідженню нещодавно описаного С825Т поліморфізму гена $\beta-3$ субодиниці G-протеїну ( $G N B 3)$, основною функцією якого $\epsilon$ передача сигналів від мембранних рецепторів до внутрішніх структур [9].

G-протеїн складається 3 трьох субодиниць $(\alpha, \beta, \gamma)$, кожна з яких, при взаємодії медіатора i G-протеїн-пов'язаних рецепторів, може активувати безліч ефекторів, таких, як іонні канали, фосфоліпазу C, аденілат-циклазну систему та ін., що, у свою чергу, призводить до клітинної відповіді, яка реалізується через гормональну секрецію. Аналіз генів $\alpha$-субодиниці $(G N A S), \beta$-субодиниці $(G N B)$ та $\gamma$-субодиниці $(G N G)$ виявив точковий поліморфізм у гені $\beta 3$-субодиниці, розташованому в хромосомі 12 p13, що полягає в заміні цито-

(C) I.O. Моісеєнко, 2015

114 хворих на АГ частіше трапляються гетерозиготи $\mathrm{C} / \mathrm{T}$ порівняно 3 контрольною групою, що є статистично вірогідним $(\mathrm{p}<0,001)$. Носії Т алеля мають ризик розвитку АГ в 2,7 раза вищий, ніж носії С алеля $(\mathrm{p}=0,002)$.

Ключові слова: артеріальна гіпертензія, С $825 \mathrm{~T}$ поліморфізм, ген $\beta 3$ - субодиниці G-протеїну.

зину (C) на тимін (Т) у 825-й позиції (С825Т). У результаті цієї мутації синтезується позбавлена 41 амінокислотного залишку, але функціонально активніша форма $\beta 3$-субодиниці G-протеїну, що призводить до зміни внутрішньоклітинної концентрації кальцію, підвищення активності натрієвопротонної помпи, збільшення внутрішньоклітинної передачі сигналів, i, як наслідок, до посиленої реакції клітин на гормональне подразнення [9].

У контрольованих популяційних дослідженнях, проведених серед європейців [12] та жителів Індії [5], продемонстровано зв'язок Т алеля з розвитком АГ. Встановлено більш високу частоту Т алеля $(0,526)$ у хворих на АГ, а також асоціацію даного поліморфізму з початком АГ у більш ранньому віці і з більш злоякісним перебігом [7]. Проте в окремих дослідженнях не виявлено асоціації 825Т алеля з АГ, раннім іï початком та із розвитком гіпертонічного кризу в пацієнтів з есенційною АГ [6]. Тому дані про зв'язок С 825 Т поліморфізму гена $\beta 3$-субодиниці G-протеїну i АГ на сьогоднішній день залишаються суперечливими.

Мета дослідження. Вивчити асоціації C825T поліморфізму гена $\beta 3$-субодиниці Gпротеїну з АГ.

Матеріал і методи. У дослідженні брали участь 155 пацієнтів із верифікованим діагнозом АГ (основна група) та 50 практично здорових осіб (контрольна група). Серед досліджуваних хворих жінок було $68(43,9 \%)$ та 87 чоловіків $(56,1 \%)$ віком $(60,8 \pm 0,8)$ років, а в групі контролю - 28 жінок (56\%) та 22 чоловіки (44\% ) віком $(51,4 \pm 2,3)$ років .

Діагноз АГ грунтувався на критеріях ВООЗ (1999) та рекомендаціях Українського товариства кардіологів (2012).

Визначення C825T поліморфізму гена GNB3 (rs5443) проводили методом полімеразної ланцюгової реакції (ПЛР) з подальшим аналізом рестрикційних фрагментів. Ділянку гена GNB3 ампліфікували за допомогою специфічних праймерів: п р я м о го ( TGACCCACTTGCCACCCGTGC-3' та зворотного (antisense) 5'-GCAGCAGCCAGGGCTGGC-3'. ПЛР проводили в термоциклері GeneAmp PCR System 2700 ("Applied Biosystems", США). Вiзya- 
лізацію ДНК проводили за допомогою трансілюмінатора ("Біоком", Росія).

Статистичну обробку даних проводили за допомогою програми SPSS Statistics 21. Статистичний аналіз розподілу частот і генотипів проводили за допомогою критерію $\chi^{2}$ (при частотах менше 5 - точний тест Фішера). Вірогідним вважали відмінності при $p<0,05$. Для опису відносного ризику розвитку захворювання розраховували відношення шансів (ВШ) та довірчий інтервал (ДІ).

Результати дослідження та їх обговорення. Частота генотипів за С825T поліморфізмом гена $\beta 3$-субодиниці G-протеїну в загальній популяції та у хворих на АГ представлена у табл. 1.

Порівняльний аналіз розподілення частот алелів і генотипів поліморфного маркера - С $825 \mathrm{~T}$ гена GNB3 виявив статистично значимі відмінності у групі хворих на АГ та групі здорових осіб $(\mathrm{p}<0,001)$. Встановлено вірогідне збільшення частоти Т алеля у два рази порівняно з С алелем у групі хворих на АГ та нижчу частоту в групі здорових осіб. У відсотковому відношені частота алеля Т у хворих на АГ в 1,5 раза вища, ніж у групі контролю. У свою чергу, частота С алеля в основній групі в 1,7 раза менша за частоту в групі контролю, що свідчить про відсутність асоціації даного алеля з ризиком виникнення АГ.
Результати аналізу ризику виникнення артеріальної гіпертензії залежно від С825Т поліморфізму гена $G N B 3$ представлені в табл. 2.

Ризик розвитку АГ у носіїв Т алеля у 2,7 раза вищий, ніж у носіїв С алеля.

Таким чином, отримані результати частоти генотипів за С825Т поліморфізмом гена $G N B 3$ у групі здорових осіб та хворих на АГ підтверджують асоціацію Т алеля з розвитком АГ.

Отримані результати демонструють вірогідну асоціацію С825Т поліморфізму гена GNB3 3 АГ, що співзвучно з даними Frey U. et al. (2003) та Siffert W. et al. (2000). Проте частота Т алеля у хворих на АГ у нашому дослідженні перевищує таку в попередніх дослідженнях і складає 0,68 проти 0,43 та 0,31 відповідно [6, 10].

В окремих дослідженнях також підтверджено зв'язок С825Т поліморфізму гена $G N B 3$ із розвитком АГ та асоціацію Т алеля з даним захворюванням у представників різних етнічних груп $[8$, 11]. Проте результати інших досліджень не виявили асоціації С825T поліморфізму гена $G N B 33$ $\mathrm{A} \Gamma$, а також продемонстрували відсутність вірогідної різниці щодо частоти Т алеля у хворих на АГ та здорових осіб. Так, частота Т алеля у хворих на АГ та здорових осіб у популяції китайців та росіян статистично не відрізнялась і становила 0,47 і 0,48, та 0,334 і 0,295 відповідно [4, 3].

Таблиця 1

Частота генотипів за C825T поліморфізмом гена $\beta 3$-субодиниці G-протеїну в загальній популяції та у хворих на артеріальну гіпертензію

\begin{tabular}{|c|c|c|c|c|c|}
\hline \multirow{2}{*}{ Показник } & \multicolumn{2}{|c|}{ Контрольна група, n=50 } & \multicolumn{2}{|c|}{$\begin{array}{l}\text { Хворі на артеріальну гіпертензію, } \\
\text { n=155 }\end{array}$} & \multirow{2}{*}{$\mathrm{p}$} \\
\hline & $\mathrm{n}$ & $\%$ & $\mathrm{n}$ & $\%$ & \\
\hline $\mathrm{C} / \mathrm{C}$ генотип & 28 & 56 & 49 & 31,6 & 0,002 \\
\hline C/T генотип & 19 & 38 & 86 & 55,5 & 0,035 \\
\hline T/Т генотип & 3 & 6 & 20 & 12,9 & 0,81 \\
\hline С алель & 28 & 56 & 49 & 31,6 & 0,002 \\
\hline Т алель & 22 & 44 & 106 & 68,4 & $<0,001$ \\
\hline \multicolumn{6}{|l|}{$\chi^{2}=50,8$} \\
\hline $\mathrm{p}<0,001$ & & & & & \\
\hline
\end{tabular}

Примітка. $\mathrm{n}$ - кількість пацієнтів; $\chi^{2}$ - критерій узгодженості Пірсона; $\mathrm{p}$ - показник вірогідності відмінностей

Таблиця 2

Аналіз ризику виникнення артеріальної гіпертензії залежно від алеля за С825T поліморфізмом гена ß3-субодиниці G-протеїну

\begin{tabular}{|c|c|c|c|c|c|c|c|}
\hline \multirow[b]{2}{*}{ Алель } & \multirow[b]{2}{*}{$\mathrm{CR}$} & \multirow[b]{2}{*}{ SE } & \multirow[b]{2}{*}{ WS } & \multirow[b]{2}{*}{$\mathrm{P}$} & \multirow[b]{2}{*}{ OR } & \multicolumn{2}{|c|}{ 95\% CI для OR } \\
\hline & & & & & & $\begin{array}{c}\text { нижня } \\
\text { межа }\end{array}$ & $\begin{array}{c}\text { верхня } \\
\text { межа }\end{array}$ \\
\hline $\mathrm{C}$ & 0,453 & 0,529 & 0,735 & 0,391 & 0,636 & 0,29 & 0,81 \\
\hline $\mathrm{T}$ & 1,013 & 0,333 & 9,240 & 0,002 & 2,753 & 1,433 & 5,290 \\
\hline
\end{tabular}

Примітка. CR - коефіцієнт регресії; SE - стандартна похибка; WS - статистика Вальда; P - статистична значущість; $\mathrm{OR}$ - відношення шансів; CI - довірчий інтервал 


\section{Висновки}

1. У хворих на артеріальну гіпертензію вірогідно частіше трапляються носії Т алеля порівняно $з$ групою контролю.

2. Ризик розвитку артеріальної гіпертензії у носіїв $\mathrm{T}$ алеля у 2,7 раза вищий, ніж у носіїв $\mathrm{C}$ алеля. Носійство С алеля $є$ прогностично сприятливим фактором щодо розвитку артеріальної гіпертензії.

Перспективи подальших досліджень. Зважаючи на неоднозначні отримані дані щодо асоціації С825Т поліморфізму гена GNB3 з АГ, Т алель гена $G N B 3$ розглядається як потенційний генетичний маркер для визначення ризику виникнення АГ, але потребує подальшого вивчення.

\section{Література}

1. Кравчук П.Г. Сучасне уявлення про значення поліморфізму генів у патогенезі артеріальної гіпертензії у хворих на хронічну серцеву недостатність: контентаналіз / П.Г Кравчук., Д.В. Ольховський, В.І. Кадикова // Клін. та експерим. патол. - 2012. - Т. 11, № 1 (39) - C. 186-190.

2. Оцінка ефективності «Програми профілактики і лікування артеріальної гіпертензії в Україні» за даними епідеміологічних досліджень / I.M. Горбась, О.О. Смирнова, І.П. Кваша [та ін.] // Артеріол. гіпертензія. -2010 . - № 6. - С. 14-17.

3. Защитный эффект полиморфизма Gly272Ser гена GNB3 в развитии гипертонической болезни и его взаимосвязь со средовыми факторами риска развития заболевания / А.В. Полонников, М.А. Солодилова, В.П. Иванов [и др.] // Терапевт. арх. - 2011. - № 4. C. $55-60$.
4. Association between the G-protein $\beta 3$ subunit C825T polymorphism with essential hypertension: a metaanalysis in Han Chinese population / J. Lu., Q. Guo, L. Zhang [et al.] // Mol. Biol. Rep. - 2012. - Vol. 39, № 9. - P. 8937-8944.

5. Association of GNB3 C825T polymorphism with plasma electrolyte balance and susceptibility to hypertension / A. Nejatizadeh, R. Kumar, T. Stobdanand [et al.] // Genet. Mol. Biol. - 2011. - Vol. 34, № 4. - P. 138-145.

6. Cooperative effect of GNB3825C-T and GPIIIa PI(A) polymorphisms in enhanced platelet aggregation / U.H. Frey, N. Aral, N. Muller [et al.] // Tromb. Res . 2003. - Vol. 5-6, № 15. - P. 279-286.

7. G protein beta3 subunit gene polymorphism in Turkish hypertensives / E. Alioglu, E. Ercan, I. Tengiz [ et al .] // Anadolu Kardiyol Derg. - 2008. - № 8. - P. 331-335.

8. Hypertension, obesity and GNB3 gene variants / M.E. Danoviz, A.C. Pereira, J.G. Mill [et al.] // Clin. Exp. Pharmacol. Physiol. - 2006. - Vol. 33, № 3. - P. 248-252.

9. Siffert W. G protein B3 subunit $825 \mathrm{~T}$ allele and hypertension / W. Siffert // Cur. Hypertens. Rep. - 2003. - Vol. 1, № 5. - P. 47-53.

10. Siffert W. Genetic polymorphism of the G-protein beta3 subunit, obesity and essential hypertension / W. Siffert, D. Rosskopf, R. Erbel // Herz. - 2000. - Vol. 1, № 25. P. 26-33.

11. The GNB3 C825T polymorphism and essential hypertension: a meta-analysis of 34 studies including 14,094 cases and 17,760 controls / P.G. Bagos, A.L. Elefsinioti, G.K. Nikolopoulos [et al.] // J. Hyprtens. - 2007. Vol. 25, № 3. - P. 487-500.

12. The human G-protein beta3 subunit C825T polymorphism is associated with coronary artery vasoconstriction / A. Meirhaeghe, C. Bauters, N. Helbecque [et al.] // Eur. Heart J. - 2011. - № 22. - P. 845-848.

\section{АССОЦИАЦИЯ С825Т ПОЛИМОРФИЗМА ГЕНА ВЗ-СУБЪЕДИНИЦЫ G-ПРОТЕИНА С АРТЕРИАЛЬНОЙ ГИПЕРТЕНЗИЕЙ}

\section{И.О. Моисеенко}

Резюме. Целью исследования было изучение ассоциации С825T полиморфизма гена $\beta 3$-субъединицы Gпротеина с артериальной гипертензией (АГ) и прогнозирование риска развития АГ. Обследовано 155 больных с АГ и 50 практически здоровых лиц. Выявлено, что у больных АГ более распространенным является Т аллель. Среди больных АГ чаще встречаются гетерозиготы $\mathrm{C} / \mathrm{T}$ в сравнении с контрольной группой, что является статистически достоверным ( $<0,001)$. Носители $\mathrm{T}$ аллеля имеют риск развития АГ в 2,7 раза выше, чем носители $\mathrm{C}$ аллеля $(\mathrm{p}=0,005)$.

Ключевые слова: артериальная гипертензия, C825T полиморфизм, ген $\beta 3$-субъединицы G-протеина.

\section{ASSOCIATION OF C825T POLYMORPHISM B3-SUBUNIT G-PROTEIN WITH HYPERTENSION}

\section{I.O. Moiseienko}

Abstract. The purpose of the study was to investigate the association of gene polymorphism C825T $\beta 3$-subunit Gprotein with hypertension and prediction of the hypertension risk. Materials and methods. 155 patients with hypertension and 50 healthy individuals were examined. We used conventional examination for the diagnosis of hypertension, moleculargenetic and statistical methods. Statistical processing of the data was performed using the SPSS Statistics 21 . The statistical analysis of the distribution of frequencies and genotypes was carried out using the test $\chi^{2}$. The differences were considered probable with $\mathrm{p}<0,05$. To describe the risk of developing the disease we calculated odds ratio (OR). Results of the study. It was established, that patients with hypertension were more common with $\mathrm{T}$ allele. Among patients with hypertension the most common have heterozygous $\mathrm{C} / \mathrm{T}$ compared with the control group which is statistically significant $(\mathrm{p}<0.001)$. T allele carriers have the risk of hypertension by 2,7 times higher than the $\mathrm{C}$ allele carriers $(\mathrm{p}=0,005)$. Conclusion. This study shows an association of C825T polymorphism gene GNB3 with hypertension.

Key words: hypertension, C825T polymorphism, gene $\beta 3$-subunit G-protein. 